\title{
Management of agricultural pesticide packaging in the Piauí Cerrado
}

\author{
Miguel Antônio Rodrigues \\ João Batista Lopes \\ Elaine Aparecida da Silva
}

${ }^{I}$ Universidade Federal do Piauí, Teresina, Piauí, Brasil.

"Iniversidade Federal do Piauí, Teresina, Piauí, Brasil.

"II Universidade Federal do Piauí, Teresina, Piauí, Brasil.

\begin{abstract}
The study aimed to analyze the role of actors in the reverse logistics chain of used pesticide packaging in the Cerrado of Piauí. To that end, interviews were conducted with representatives of chain agents in the four municipalities that most produce soy in Piauí. Representatives of the Receiving Centers of the Agricultural Defense Agency of Piauí, business agriculture and family farming participated in the research. It was found that, despite positive initiatives of packaging receiving center operators, agricultural producers and the government, there is much to be done to minimize the negative impacts on nature and the consequent damage to people's health, as there are flaws in the official mechanisms for inspecting agricultural production units that make daily use of pesticides. Thus, joint action in the reverse logistics chain is necessary, initiated by the public authorities and disseminated to the rest of the chain participants.
\end{abstract}

Keywords: business and family farming, reverse logistics, inspection.

São Paulo. Vol. 24, 2021

Original Article

DOI: http://dx.doi.org/10.1590/1809-4422asoc20200071r1vu2021L4AO 


\section{Introduction}

Since 2008 Brazil has been the world's leading consumer of agricultural pesticides with consequences for its public health that extend to vast areas of the country and affect different population groups such as agricultural workers, residents in the vicinity of the manufacturing plants and crop farms, in addition to ordinary consumers of contaminated food products (LARA et al., 2019; FACCHINI; SOUZA, 2015). It must be underscored that since the beginning of 2019 a record number of new chemicals has been approved for sale, boosting Brazil's position as leading consumer of such products. Agricultural pesticides and similar products can be defined as products and agents of chemical, physical and biological processes designed to alter the composition of the fauna or the flora with a view to preserving them from the harmful action of living beings considered to be pests (BRASIL, 1989).

In the 1970, environmental policy began to acquire greater visibility and consequently scientific research studies addressing it became more frequent. Given that agriculture draws heavily on natural resources, the question arose at the time as to how agricultural practices could be compatibilized with environmental sustainability. In that context issues such as pollution, the effects of pesticide applications and other aspects became the themes of seminars and publications in journals and books. Rachel Carson's outstanding book 'Silent Spring', published in 1962, boosted the whole discussion of how to regulate the indiscriminate use of synthetic pesticides in agricultural areas used to control insects considered to be pests; a discussion that eventually led to changes in environment-related legislation.

There are many problems associated to the proper use of agricultural pesticides especially regarding the amounts to be used and precautions to ensure the safety of the users themselves and the population at large. Every year, 200 thousand people die from pesticide intoxication and their use destroys natural resources, affects the health of agricultural workers and the population at large, as well as sustaining an unjust production model (GREENPEACE, 2019) whereby the owners of the means of production concentrate the income and exploit the cheap labor of the working class.

Another problem associated to the use of agricultural pesticides that has many negative impacts is the handling and final disposal of the packaging. It is material that poses a high risk to biodiversity since all the dangerous properties of the pesticides are transmitted to the packaging, which makes it necessary to work with reverse logistics with a view to mitigating those impacts.

In this context, reverse logistics is an instrument for social and economic development characterized by a set of actions, procedures and means designed to implement the collection and return of solid waste to the corporate sector of origin for re-cycling or re-use in its own or other production cycles or to proceed to an environmentally suitable disposal of the material (BRASIL, 2010). This is an important tool for actors in the respective chain such as manufacturers, traders, farmers, government authorities and the empty pesticide packaging receiving centers, and unless a reverse logistics system is installed, the packaging materials are likely to be buried, burned, thrown into water courses or simply 
dumped in the open air with no prior precautions taken and, consequently, they end up polluting the environment (INPEV, 2019).

Brazil's National Solid Waste policy (Política Nacional dos Resíduos Sólidos) imposes on the pesticide production chain, shared responsibility for structuring and implementing it, to ensure that the packaging is returned to the manufacturers (BRASIL, 2010).

The practice of reverse logistics originated from the need to address, not only environmental considerations but also financial and legal issues. The environmental motivation may be for a question of conscience and awareness or because of legal imposition but, either way, it brings with it benefits for the environment and even favors the environment that the manufacturing company is situated in. The financial motivation is associated to the gains obtained with the re-use of packaging materials or of raw materials (COUTO; LANGE, 2017).

The high productivity of grain crops cultivated in the Cerrado of Piaui state is largely responsible for the economic growth of municipalities situated in that phytogeographic domain where large-scale agriculture is practiced. Outstanding evidence of that is the high value of the per capita GDP in the municipalities of Uruçuí, Bom Jesus, Baixa Grande do Ribeiro and Ribeiro Gonçalves: $\mathrm{R} \$ 36,777.46, \mathrm{R} \$ 21,051.99, \mathrm{R} \$ 20,938.40$ and $\mathrm{R} \$ 17,232.04$, respectively, whereas the per capita GDP for the state of Piaui as a whole is only $\mathrm{R} \$ 12,890.00$ (IBGE, 2018). Piauí is part of the region known as MATOPIBA, outstanding in the production of grains in Brazil's new agricultural frontier, formed by parts of the states of Maranhão, Tocantins, Piaui and Bahia.

This study addresses the need for a better understanding of the reverse logistics dynamics of used agricultural pesticide packaging in the Cerrado savannahs of the state of Piaui. The scope of the logistics should involve the performance of the activities provided for in the terms of the specific legislation and the integration of the components of the chain in such a way as to ensure the adequate final disposal of the packaging.

To that end the study set out to analyze the role of each actor in the reverse logistics chain of the packaging of agricultural pesticide packaging used in crop farming in the Cerrado of Piaui from the perspective of environmental sustainability.

\section{Methodological procedures}

This primary research study was conducted in those municipalities of the state of Piaui in which soy crop farming has emerged in the forefront of large-scale agriculture in its Cerrado savannahs although other crops are also planted in the region. According to the IBGE (2018), the main soy producing municipalities in Piaui are, in order of production figures: Baixa Grande do Ribeiro, Uruçuí, Ribeiro Gonçalves, Bom Jesus, Santa Filomena, Gilbués, Currais, Sebastião Leal, Monte Alegre do Piauí and Corrente. They are the ones with the largest areas dedicated to large scale grain crop plantations and consequently the ones that most make use of agricultural pesticides on their crops. The study selected four of them as being the most representative of the region, namely, Baixa Grande do Ribeiro, Uruçuí, Ribeiro Gonçalves and Bom Jesus. 


\section{Research Participants}

The agents of the reverse logistics chain associated to agricultural pesticide packaging materials are the pesticide manufacturers, the pesticide users, the public authorities and the receiving centers or posts for used packaging. The study analyzed how each of the actors in the reverse logistics chain performed their function by accompanying their activities at the operational and strategic levels.

The National Empty Packaging Processing Institute for Processing (Instituto Nacional de Processamento de Embalagens Vazias - INPEV) is a non-profit institution founded in 2001 by the agricultural pesticide manufacturing industry to promote, in the whole of Brazil, the correct disposal and destination of this kind of packaging after consumption of the product, in compliance with the terms of Federal Law no 9.974/00. In addition to the 110 receiving centers there are 301 collection posts, totaling 411 receiving units for Brazil as a whole. Only three of them are located in Piaui, in Bom Jesus, Uruçuí and Teresina (INPEV).

\section{Data gathering}

The study analyzed and verified how manufacturers' shoulder their responsibilities by examining the records of the agricultural production units regarding their routines for gathering and delivering the used packaging, and those of the used packaging receiving/ commercializing centers, to obtain a panorama of the manufacturers' performance in regard to the final disposal of the packaging.

In the receiving units, the study analyzed how they handled and treated the material, the degree of their outreach to the grain production areas, the percentage of adherence to the reverse logistics chain and the extent of chain integration. To that end a semistructured interview was conducted with the representative of the Bom Jesus center and an in loco analysis of the routine of the workers handling the returned packaging material.

In regard to the institutional role of the public authorities in the chain, the study investigated the performance of the Piaui Agricultural Defense Agency (Agência de Defesa Agropecuária do Piaui - ADAPI) in licensing and inspection activities.

In the agricultural production units at both the business and family farming levels, the study conducted semi-structured interviews with their representatives to obtain information, especially regarding their experiences, engagement in the process, difficulties and results.

The Piaui Agricultural Defense Agency (ADAPI) records show that it is active in 60, 80, 15 and 15 large-scale grain producing units in the municipalities of Bom Jesus, Uruçuí, Baixa Grande do Ribeiro and Ribeiro Gonçalves, respectively. However, for family farming units, it was impossible to obtain the exact number of establishments but the IBGE (2018) statistics from the 2017 Farming Census show that the numbers of establishments are as follows: Bom Jesus - 1,024; Uruçuí 1,221; Baixa Grande - 913; Ribeiro Gonçalves - 345. 
Researchers interviewed 40 business agriculture representatives (20 from Uruçuí, 10 from Bom Jesus, 5 from Baixa Grande do Ribeiro and 5 from Ribeiro Gonçalves), and 60 family farming representatives (25 from Uruçuí, 15 from Bom Jesus, 10 from Baixa Grande and 10 from Ribeiro Gonçalves).

Information was obtained on pesticide users' habits regarding their purchase and use of pesticides and how they disposed of the packaging. Agricultural production unit representatives were queried as to how much they knew about the reverse logistics process chain, the final destination of the packaging and any problems associated to the management of that process.

The questions in the semi-structured interviews were designed to reveal what motivated the interviewees to adopt the reverse logistics practices, what they knew about its initial implementation in the light of the respective regulations and their opinions regarding the presence or absence of government bodies in that process.

The Research Project Proposal was submitted to the Research Ethics Committee of the Federal University of Piauí which issued a Certificate of Presentation for Ethical Appreciation CAAE no 03625618.0.0000.5214 and Consubstantiating Technical Opinion 3.131.007 on February 4, 2019, authorizing the research. Accordingly, field visits and interviews duly took place in the period from February 05 to July 11, 2019.

The data obtained was tabulated in Excel spreadsheets and then processed to obtain the central tendency and dispersion measurements for the quantitative variables and identify the dominant spectrum for the qualitative ones.

The study adopted a descriptive qualitative approach gathering information from ADAPI representatives in four grain-producing municipalities in the state of Piauí, namely, Bom Jesus, Uruçuí, Baixa Grande do Ribeiro and Ribeiro Gonçalves. Another participant was the representative of the pesticide packaging receiving center in the municipality of Bom Jesus. It was not possible to interview personnel from the Uruçuí Center which receives such material from the municipalities of Baixa Grande do Ribeiro and de Ribeiro Gonçalves because their representatives did not give permission to do so.

The selection of municipalities to participate in the study was based on the criteria that there should be a receiving center in the municipal capital or in nearby municipalities, that receiving of the material should be made in the installations of the center itself or by some itinerant collection scheme and that the municipalities should have a considerable participation in regional grain production.

The selection of institutions and individuals to participate was based on their attributions in the packaging reverse logistics chain in which the Receiving Centers have the function of managing the reception of the material and issuing documents attesting their effective return by product users, in addition to directly participating in environmental education and awareness-raising activities, especially in aspects related to pesticide use. The ADAPI was selected due to the fact that "all pesticides or similar materials for use in agriculture, pastures or the protection of planted forests, if they are to be transported, stored, commercialized or used in the State of Piauí, must be duly registered with the ADAPI and the Ministry of Agriculture, Livestock and Supply (Ministério da Agricultura, 
Pecuária e Abastecimento - MAPA) or IBAMA" (ADAPI, 2019).

\section{Results and discussion}

The results of this research portray the performances of four types of agents of the pesticide packaging reverse logistics chain in the Cerrado of Piauí, namely, the used packaging receiving center, the Piauí Agricultural Defense Agency (Agência de Defesa Agropecuária do Piauí - ADAPI), family farmers and agribusiness farmers.

\section{The performance of the pesticide packaging receiving centers}

There are three centers for receiving used pesticide packaging in the state of Piauí located in the municipalities of Bom Jesus, Uruçuí and Teresina and they are managed by the Piauí Cerrado Commercial Association (Associação Comercial do Cerrado Piauiense ACOCEP). However, the centers in Uruçuí and Teresina are administered by the National Used Packaging Processing Institute (Instituto Nacional de Processamento de Embalagens Vazias - INPEV) and that institute did not authorize the participation of those units suggesting that, instead, the study should gather information from its site http://inpev.org.br.

That meant the field study of pesticide packaging receiving was restricted to the municipality of Bom Jesus alone. So the respective data was gathered at the Bom Jesus center which, as it happens, also receives material from rural properties in the neighboring municipalities of Corrente and Gilbués that are nearer to it than the centers of their own municipalities.

Although Uruçui has its own center for the receiving of used pesticide packaging, many of its crop farmers prefer to return the packaging to the center in Bom Jesus. A case in point is one of the districts of Uruçuí, Nova Santa Rosa, which is $160 \mathrm{~km}$ away from the city of Uruçuí but only $120 \mathrm{~km}$ from Bom Jesus. Furthermore, the transportation logistics in Uruçuí are precarious as the roads are unpaved and in the rainy season the trucks loaded with grain face great difficulties transporting it.

Considering the results obtained in loco from the visits to the installations of the association, together with the activities performed by the receiving center the following main reverse logistics procedures and actions were verified:

a) Reception of the empty packaging/containers, visual inspection, screening, cleaning (removal of caps or labels), followed by separation of the materials by types.

b) Separation of the packaging suitable for incineration (flexible material - plastic bags, paper bags, cardboard boxes and the seed treatment packaging which although it is not flexible is too dense for integral washing. Also, washable containers which the proprietor has failed to subject to the triple washing process are identified by the absence of perforations that ensure their non-reutilization;

c) Compaction of each type of material into bales of maximum $65 \mathrm{~kg}$ to compose cargoes of at least $13,500 \mathrm{~kg}$; 
d) Commercialization of the packaging;

e) Actions in the Municipal Education system promoting talks during $\mathrm{Na}$ tional Environment Week and establishing partnership arrangements with the Municipal Education Department;

f) Environmental awareness-raising activities in schools in the interior regions of the municipality;

g) Joint actions with the Municipal Education Department;

h) Provision of an itinerant package receiving service.

In Brazilian law, Act no 9.974/2000 (BRASIL, 2000) determines the centers' activities to be: a) Receiving used washable and non-washable containers/packaging; $b$ ) inspecting and classifying such packaging; c) Compacting materials by types; d) issuing a receipt that confirms packaging delivery on the part of farmers as well as unfolding environmental awareness-raising activities.

In the case of the center under study, the study verified, via its representative, that there is effective action on its part in alignment with the obligations for receiving centers or posts determined by the respective Act, namely, receiving used pesticide packaging , inspecting and classifying it as washable or non-washable issuing a receipt confirming delivery, separating and compacting the packaging according to type then issuing a collection order so that the INEPV can provide transportation to the final destination (CONAMA, 2014).

The Bom Jesus used pesticide packaging receiving center also operates itinerant receiving activities with a vehicle that travels to certain areas where family agriculture is practiced and pesticide use is relatively low compared to agribusiness use and furthermore, family agriculture farmers often do not return used pesticide packaging. To ensure efficacy of the service, the schedule of its itinerary is made known in advance so that farmers can plan their journey to the collecting point. Thus the family farmers are given an opportunity to return the packaging without having to travel all the way to the center. Nevertheless, every one of the 60 farmers representing that group stated that they do not return used packaging because they consider burning it to be a better solution as, in their view, it is the fastest way of eliminating it.

The representative of the Bom Jesus center declared that in the conditions in which it currently operates, there was no way they could verify any kind of resistance on the part of the farmers. He considers however and that the current system is efficient. Furthermore, the representative informed researchers that there is a regional council of centers (North-Northeast) in existence which evaluates the entire operational system, safety aspects, possibilities and suggestions and updating. There are also meetings held at the national level to analyze the system in aspects ranging from the need to install new centers, to the emergence of new technology and more flexible packaging.

The legal requirements (BRASIL, 2014) for the authorization of a new pesticide packaging receiving center to function are that it must, at the very least, present a man- 
agement plan establishing and providing:

a) actions inserted in an educational program designed to raise-awareness of communities in the surrounding areas regarding the center's operations of reception, temporary storage and forwarding to its final destination of used packaging of pesticides or similar substances, whether totally empty or containing residues, returned by the pesticide users;

b) a capacity-building program for all operators or handlers involved regarding the activities to be carried out in the centers with certification for participants;

c) an environmental risk prevention program and periodic monitoring of all center workers' health in accordance with the terms of the Ministry of Labor and Employment and Ministry of Health regulations in force;

d) an accident prevention and control plan; and

e) a system to control the entrance and exit of the used packaging of agricultural pesticides and similar substances or that contain pesticide residues, and that issues periodic reports identifying the owners of the packaging material, the amount and type delivered and the final destination.

During the visit to the Bom Jesus center it was possible to observe that the legal requirements were entirely met insofar as it is located in a rural area with due physical structure and correct handling and storage of the packaging material (Figure 1) and the center also performs the recommended actions of environmental awareness-raising.

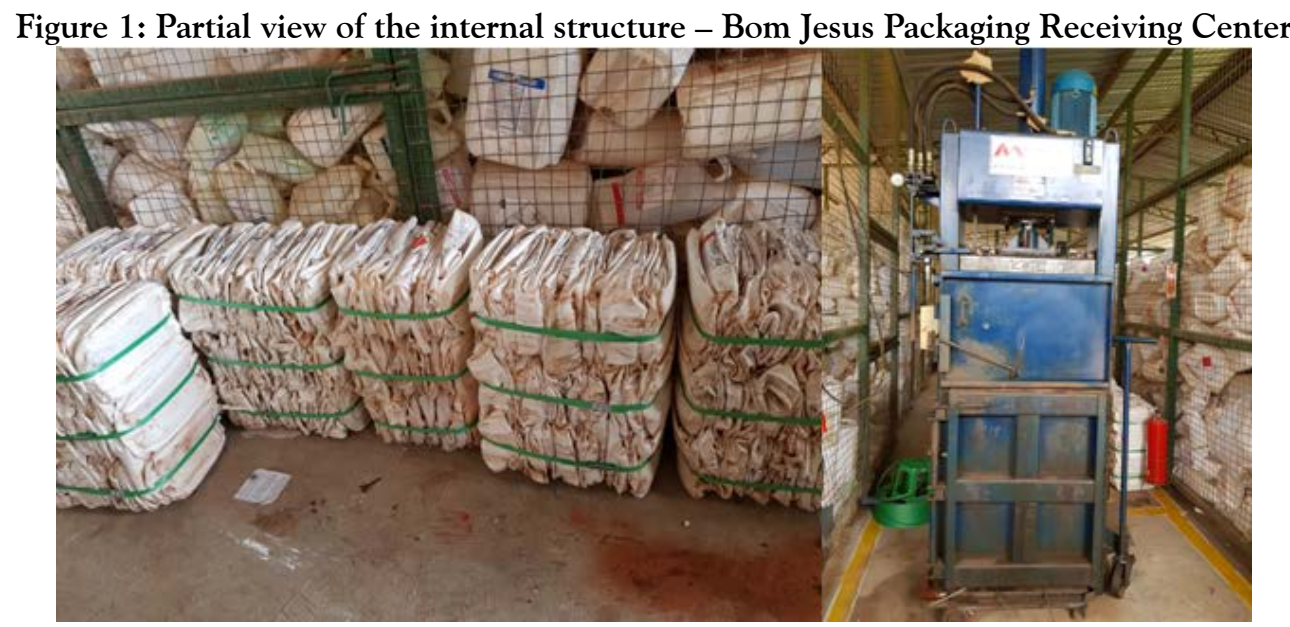

Source: authors' collection (2021).

The receiving center for empty pesticide packaging in question is located in the rural zone of the Bom Jesus municipality, far from any residences or commercial establishments in compliance with the provisions of CONAMA Resolution № 465/2014 concerning the location of such centers (BRASIL, 2014). That is to ensure that there is no possibility of pesticide packaging remnants, carried by the wind or other means, entering in contact with residences or any other place where people circulate. 
Figure 2 displays the quantities of packaging in tons per annum that the Bom Jesus pesticide packaging receiving center processed in the years 2007 to 2018. The figures reveal the center's importance, given the great quantities of packaging used by agricultural producers in the municipality of Bom Jesus and surrounding region, approximately 3,323 tons over the period. That makes its activities highly important in regard to nature conservation and also to the fact that it generates employment, thereby fostering social and economic benefits.

Figure 2: Quantities of packaging received by the Bom Jesus center in the period 2007 to 2018.

Source: Field research (2021)

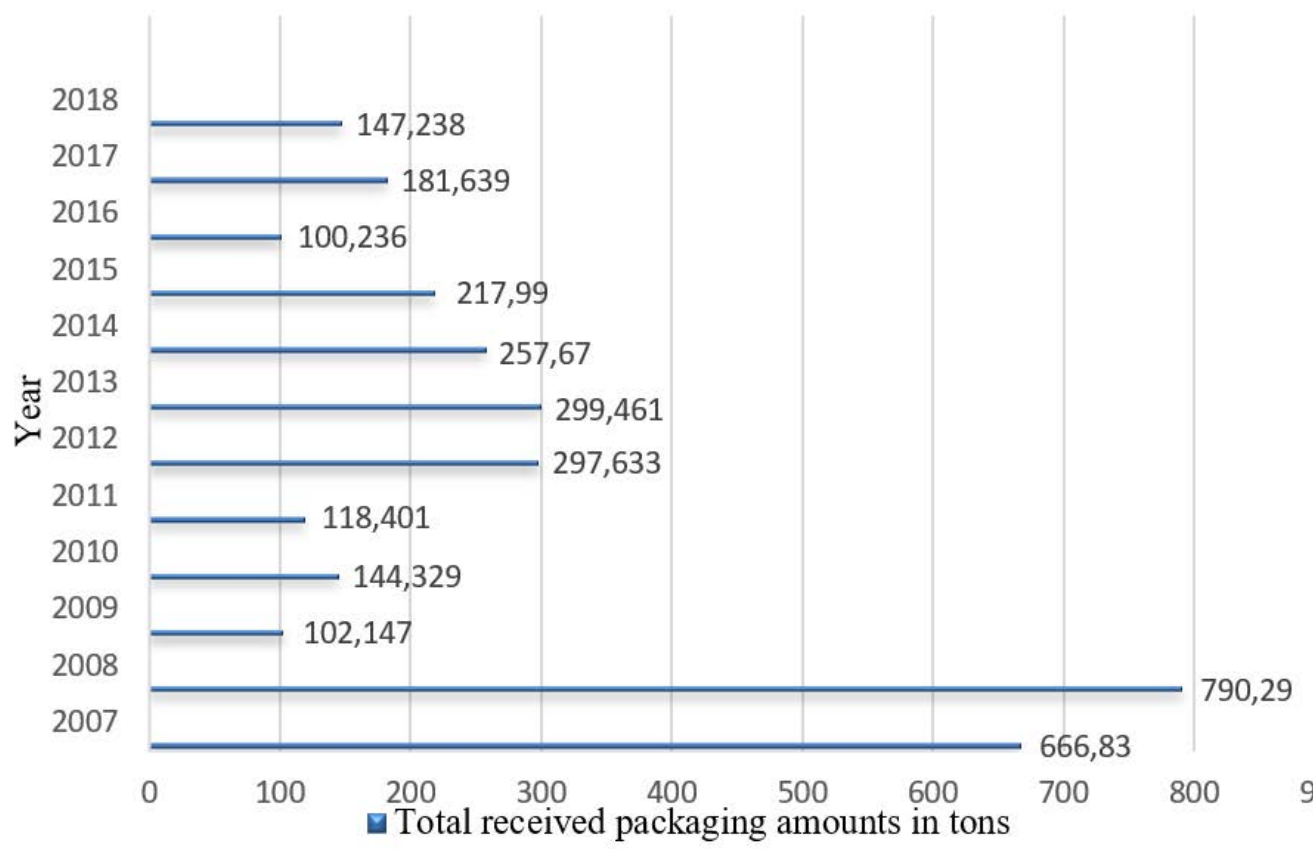

Padilha (2018) states that, prior to the mid-1990s, the companies that produced agricultural pesticides in Brazil were highly irresponsible in environmental terms and for decades disrespected environmental quality standards, elementary risk management procedures, and control of solid waste contamination of the environment and human health, all of which was fostered/facilitated by loopholes in the respective legislation and flaws in the inspection system in Brazil. In that light, the Bom Jesus receiving center is a positive step forward in terms of complying with the laws and regulations (CONAMA № 465/2014) and concern for the negative impacts that pesticide residues can give rise to.

Performance of Inspection and Surveillance Entities 
Government authorities are responsible for inspecting the proper use of agricultural pesticides and they are important links in the pesticide packaging reverse logistics chain. In the municipalities studied by this research that responsibility lies with the Piauí Agricultural Defense Agency (Agência de Defesa Agropecuária do Piauí - ADAPI).

The ADAPI is outstanding among the other public bodies that participate in the processes of pesticide use authorization and inspection because it is closer to the agricultural production areas and responsible for actually visiting and supporting them. ADAPI plays a fundamental role in inspecting rural properties that make use of agricultural pesticides in addition to being responsible for licensing their use; hence the overriding importance of its participation in this research.

The study interviewed the local ADAPI coordinators in the municipalities covered by the research to gain information on the working routines of farmers in regard to their handling and storage of pesticides and of the empty packaging, verifying ADAPI's performance and its diagnosis regarding the scenario in the grain producing properties in regard to pesticide use. The ADAPI unit in Baixa Grande do Ribeiro extends its activities to those of Ribeiro Gonçalves and Baixa Grande.

In response to questions as to the percentage of farming establishments that return used pesticide packaging within the time period established by law the coordinators stated that:

a) In the municipality of Bom Jesus, family agriculture farmers do not return the packaging and that in their visits of inspection, they have come across cases of rigid containers being re-used to store water. On the other hand, around $20 \%$ of agribusiness farmers fail to return the packaging in the recommended time or to store the material properly. However, visits of inspection have not been regularly carried out due to the insufficient provision of personnel and fuel;

b) In the municipality of Uruçuí, according to the representatives, the family agriculture farmers do not return the used packaging, but the large-scale crop farmers do and they comply with all the regulations in force. However, there are difficulties to get to some of the properties and that can jeopardize the inspection process;

c) In the municipalities of Baixo Grande do Ribeiro and Ribeiro Gonçalves (a single ADAPI unit in the former municipality accompanies both of them), the agribusiness farmers were comparatively in order with their obligations to return pesticide packaging but the visits of inspection have not been regularly made for lack of transportation structure and financial and human resources.

In regard to resistance encountered by ADAPI inspectors on the part of large-scale agricultural producers they identified the following irregularities in all the municipalities embraced by this study: agricultural pesticides and their used packaging stored in inadequate locations such as machinery patios and others not meeting the legal requirements; expired pesticides kept in non-isolated, unidentified storage spaces; agricultural pesticides and similar products purchased without the emission of the sales bill or agronomic prescription document; non-use of Personal Protective Equipment (PPE) during the application and/or handling of pesticides and similar products; and the absence of responsible technical personnel during 
pesticide application.

The reluctance of the farmers of the studied production units to follow the legally required procedures reveals the fragility of the current inspection system regarding pesticide use. The consequences go beyond the boundaries of those agricultural production units given that the substances that compose the pesticides can be dispersed in the environment and even be present at the table of people consuming contaminated food products.

In the view of Carneiro (2015), pesticides can affect people directly, as witness the increasing numbers of cases of intoxication, or indirectly, insofar as the intensifying use of pesticides is a phenomenon intrinsically associated to the expansion of globalized food production systems and the corresponding changes in the population's dietary habits involving ever greater consumption of ultra-processed high-calorie food containing ingredients that are harmful to health.

In regard to temporary storage in unsuitable places, in the field visits to the agricultural production units, it was possible to observe such situations. On one farm, the used packaging was stored in a shed together with building materials and agricultural machines and implements (see Figure 3) whereas the law requires that they should be stored in isolated locations until they can be transported to a receiving center or collecting post (BRASIL, 2000).

Figure 3: Agricultural pesticides kept in an unsuitable place

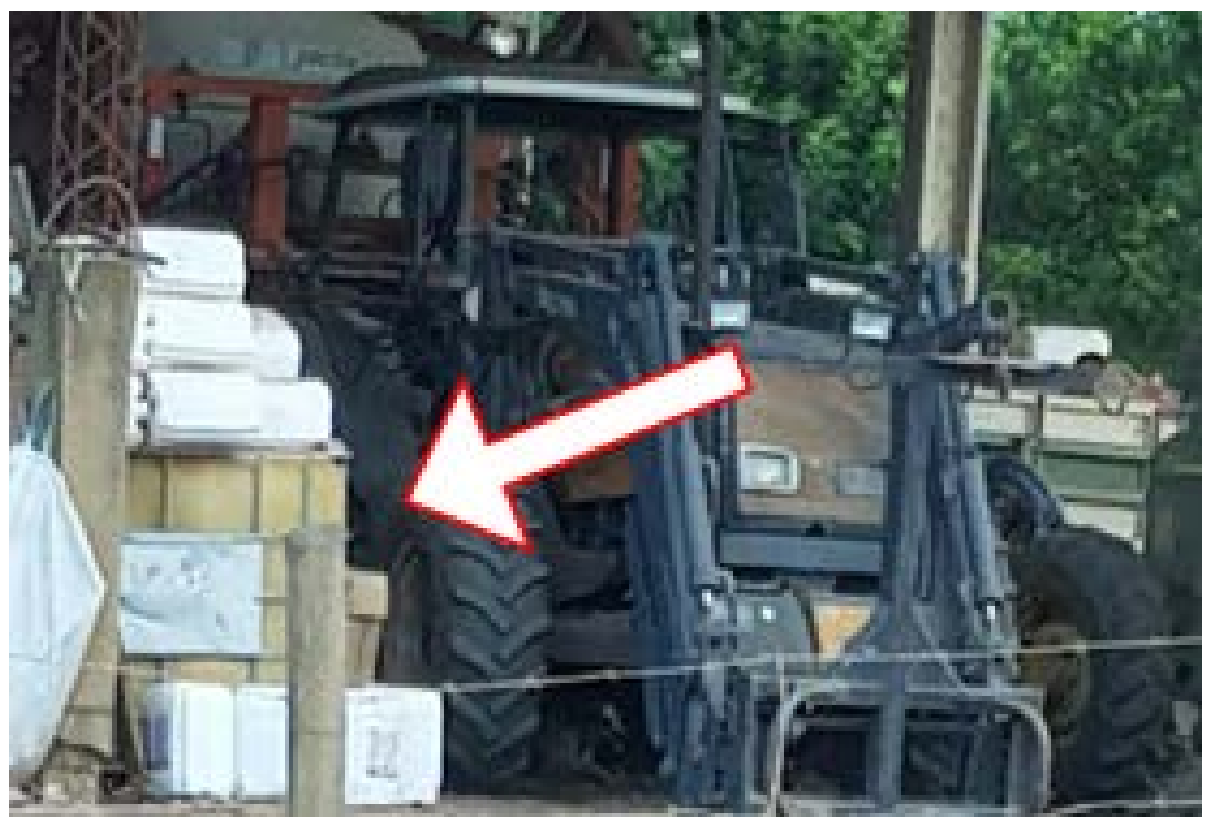

Source: authors' collection (2021).

Regarding ADAPI's internal limitations to the execution of its functions, its representatives mentioned the lack of infrastructure, especially transportation logistics for 
the inspectors to get to the agricultural production properties and the small number of personnel effectively operating it. That is a portrait of an inoperant system in a chain in which if one of the actors is not acting effectively it will jeopardize the functioning of the entire chain.

Performance of pesticide users at the agribusiness and family agriculture levels

The agribusiness farmers representatives declare that they use Personal Protective Equipment (PPE) in the processes of preparing and applying agricultural pesticides and in addition they instruct their employees to make use of them insofar as the employees have to sign a term of receipt of the respective equipment. Among the family agriculture practitioners, $25 \%$ declared that they used such equipment but $75 \%$ declared that they did not, alleging that they only used pesticides occasionally. Brazilian farmers justify that low rate of use of PPE (SOUSA et al., 2016) arguing that the high temperatures they work in make PPE use highly uncomfortable and furthermore it represents an additional cost for them to meet (LIMA et al., 2015). While the PPE is not sufficient to entirely protect workers from developing chronic diseases the fact does not relieve employers from the responsibility of strict inspection of equipment use by the workers because inadequate use of such equipment contributes to the high numbers of accidents with pesticides.

Family agriculture farmers state that they burn empty pesticide packaging right after they use the product. All the agribusiness representatives stated that they devolve the rigid (washable) packaging. In regard to the non-washable (flexible) packaging, however, $57.5 \%$ of that group declared that they do not return the packing because the amounts are too small and in fact, they burn it. The other $42.5 \%$ systematically return such packaging.

It must be underscored that causing any level of environmental pollution of any kind that harms human health or causes the death of animals or significant destruction of the flora is a crime. If that crime involves the disposal of solid, liquid or gaseous waste or debris, oils or oily substances in discordance with the legal requirements set out in the respective laws and regulations, then the perpetrator is liable to imprisonment for up to five years (BRASIL, 1998).

The pro-environment role of public institutions and the receiving centers in regard to awareness-raising does not seem to be achieving any effective results insofar as family agriculture farmers are unaware of the harm caused by their customary practice of getting rid of toxic substance packaging, such as that of the pesticides they use, by simply burning it. The existence of extensive legislation designed to protect the environment is, in practice, ineffective.

In regard to the temporary storage places for used packaging, all those interviewed declared that a specific location was designated for that purpose. Nevertheless, from observations in loco, it was possible to see the material stored in trailers alongside other agricultural machinery as shown in Figure 3.

In regard to the average length of time the used packaging material remains in the crop producing areas, $75 \%$ state that it remain there for six months to a year because they 
find it difficult to schedule a delivery date with the receiving center and often cannot get the date they would prefer and furthermore, if for some unforeseen circumstance they are unable to deliver on the allotted date, there is a lack of flexibility in the rescheduling process.

In regard to individual declarations, each of the agribusiness representatives declared that they return $100 \%$ of washable packaging and in regard to that being a collective practice of the category as a whole they believed that $80 \%$ of agribusiness farmers do so.

In regard to bearing the costs of treatment and material and reverse logistics of the packaging, the agribusiness farmers stated that they always bore those costs and that the main obstacle to returning the material was logistics infrastructure and secondly the performance of the packaging receiving center. $80 \%$ of them stated that they were aware of the respective legal sanctions, but they had never been punished for anything associated to failure to comply with the legislation. They insisted that the main motivation for returning the material was the fact that it was a legal requirement and also their concern for the harm such packaging material might cause to the environment if it were inadequately disposed of.

When questioned as to their knowledge of cases of employees or other persons that had become ill through contact with pesticides or the respective packaging, all the respondents in both groups (agribusiness farming and family farming) replied that they did, but in other municipalities than their own. In regard to their opinions as to what the main negative impacts that result from disposing packaging waste in the environment were, they mentioned most: contamination of water courses and bodies, human health problems and harm to the fauna and flora.

In answer to the question as to how the efficiency of the reverse logistics process of used pesticide packaging could be improved, $80 \%$ of the agribusiness representatives believed that it could be by implanting a total tracking system of the product right through to the final return of the packaging. Among the family farming representatives, $70 \%$ considered that the public authorities should intensify inspection.

In 2014 the Permanent Campaign against Agricultural Pesticides and for Life (Campanha Permanente Contra os Agrotóxicos e Pela Vida) defined a five-point priority agenda of strategic measures to be taken:

1. Banishing pesticides already banned by other countries.

2. Ending tax exemption for pesticides.

3. Ending aerial crop-spraying.

4. Defending pesticide-free water.

5. Consolidating areas free from pesticides and transgenic crops (BÚRIGO, et al., 2015, p. 487).

Contrary to that agenda, however, the current Brazilian government has taken steps to facilitate pesticide use, authorizing the use of new products or of formerly forbidden products so that there has been a record number of authorizations for such products over the last ten years as can be seen from the following chronological sequence: in 
2010, 104; in 2011, 146; in 2012, 168; in 2013, 110; in 2014, 148; in 2015, 139; in 2016, 277; in 2017, 405; in 2018, 449; and in 2019, 474 (Ministério da Agricultura, Pecuária e Abastecimento - MAPA, 2019) while at the same time reclassifying them to categories supposedly with softer impacts on biodiversity, people's lives and the environment.

\section{Conclusions}

It can be safely stated that a significant part of the actions designed to carry out the reverse logistics of agricultural pesticide packages in the Cerrado of Piauí are being put into practice. An example is the activities undertaken by the Bom Jesus Municipal Association (Associação do município de Bom Jesus) which meets the requirements for putting a form of environmental education into practice that seeks to raise society's awareness in regard to the importance of taking care of the environment in ways that are accessible to those engaged in family agriculture thereby facilitating the process of their returning the packaging of the pesticides they use. However there is still much to be done in regard to ensuring compliance with the provisions of the National Solid Waste Policy (Politica Nacional de Resíduos Sólidos - PNRS).

On the Other hand, the entity responsible for inspecting agricultural pesticide use in the region, the Farming Defense Agency (Agência de Defesa Agropecuária - ADAPI) lacks infrastructure compatible with the activity's complexity, given the huge territorial extension of the municipalities in this study. The agricultural production units are often far from the cities so that an appropriate provision of transportation logistics and personnel is needed to make rural zone monitoring feasible. That was revealed when the study found that each ADAPI unit has very scant financial resources to cover the costs of transportation from the center to the respective crop production units.

Most people engaged in family agriculture use agricultural pesticides but do not return the packaging; a serious factor that contributes to environmental pollution and at the same time shows the need for raising awareness of the production system as a whole to endeavor to include this group in the pesticide packaging reverse logistics chain.

In the agribusiness sector, businessmen partially meet the requirements for a proper reverse logistics flow for the packaging of the products they use insofar as they return all of the washable packaging. However, in regard to the non-washable (flexible) packaging, while most do indeed return the material there is still a considerable portion of them that burn it which is an eminently unsustainable act.

\section{References}


ADAPI. Cadastro de agrotóxicos. Available at http://www.adapi.pi.gov.br/agrotoxicos/cadastrode-agrotoxicos. Acessed on: March 05, 2020.

BRASIL. Resolução n⿳2 2.080, de 31 de julho de 2019. Divulga a reclassificação toxicológica de acordo com o disposto na Resolução da Diretoria Colegiada - RDC n 294, de 29 de julho de 2019, baseada nos critérios definidos pelo Sistema Globalmente Harmonizado de Classificação e Rotulagem de Produtos Químicos (GHS). Diário Oficial da República Federativa do Brasil, Brasília, DF, 31 julho 2019.

BRASIL. Associação Brasileira de Normas Técnicas (ABNT, 1997) - NBR 13968 - Embalagem Rígida Vazia de Agrotóxico: Procedimentos de Lavagens. Available at: https:/pt.scribd.com/ doc/30905105/Abnt-Nbr-13968-Embalagem-Rigida-Vazia-de-Agrotoxico-Procedimentos-deLavagens. Accessed on: February 02, 2020.

BRASIL. Lei no 12.305, de 2 de agosto de 2010. Institui a Política Nacional de Resíduos Sólidos; altera a Lei no 9.605, de 12 de fevereiro de 1998; e dá outras providências. Diário Oficial da República Federativa do Brasil, Brasília, DF, 3 Agosto 2010.

BRASIL. Resolução CONAMA № 465/2014 - Dispõe sobre os requisitos e critérios técnicos mínimos necessários para o licenciamento ambiental de estabelecimentos destinados ao recebimento de embalagens de agrotóxicos e afins, vazias ou contendo resíduos. Diário Oficial da República Federativa do Brasil, Brasília, DF, 08 dezembro 2014.

BRASIL. Lei no 9.974, de 06 de junho de 2000. Altera a Lei no 7.802, de 11 de julho de 1989, que dispõe sobre a pesquisa, a experimentação, a produção, a embalagem e rotulagem, o transporte, o armazenamento, a comercialização, a propaganda comercial, a utilização, a importação, a exportação, o destino final dos resíduos e embalagens, o registro, a classificação, o controle, a inspeção e a fiscalização de agrotóxicos, seus componentes e afins, e dá outras providência. Diário Oficial da República Federativa do Brasil, Brasília, DF, 06 Junho 2000.

BRASIL. Lei no 7.802, de 11 de julho de 1989. Lei dos Agrotóxicos. Diário Oficial da República Federativa do Brasil, Brasília, DF, 12 Julho 1989.

BRASIL. Lei no 9.605, de 12 de fevereiro de 1998. Dispõe sobre as sanções penais e administrativas derivadas de condutas e atividades lesivas ao meio ambiente, e dá outras providências. Diário Oficial da República Federativa do Brasil, Brasília, DF, 13 Fevereiro 1998.

BRASIL. Classificação dos imóveis rurais (2018). Instituto Nacional de Colonização de Reforma Agrária. Available at: http://www.incra.gov.br/tamanho-propriedades-rurais. Accessed on: February 27, 2020.

BRASIL. Li no 8.629, de 25 de fevereiro de 1993. Dispõe sobre a regulamentação dos dispositivos constitucionais relativos à reforma agrária, previstos no Capítulo III, Título VII, da Constituição Federal. Diário Oficial da República Federativa do Brasil, Brasília, DF, 26 fevereiro, 1993.

BÚRIGO, A. C.; et al.. Parte 4 - agricultural pesticides crise do paradigma do agronegócio e as 
lutas pela agroecologia: As Lutas contra os Agrotóxicos na Sociedade civil e em Instituições Públicas. In: CARNEIRO, Fernando Ferreira (Org.) Dossiê ABRASCO: um alerta sobre os impactos dos agrotóxicos na saúde / Organização de Fernando Ferreira Carneiro, Lia Giraldo da Silva Augusto, Raquel Maria Rigotto, Karen Friedrich e André Campos Búrigo. - Rio de Janeiro: EPSJV; São Paulo: Expressão Popular, 2015. 624p. Available at: https://www.arca.fiocruz.br/bitstream/icict/26221/2/Livro\%20EPSJV\%20013036.pdf. Accessed on: March 23, 2020.

CARNEIRO, F. F. (Org.) Dossiê ABRASCO: um alerta sobre os impactos dos agrotóxicos na saúde / Organização de Fernando Ferreira Carneiro, Lia Giraldo da Silva Augusto, Raquel Maria Rigotto, Karen Friedrich e André Campos Búrigo. - Rio de Janeiro: EPSJV; São Paulo: Expressão Popular, 2015. 624 p. Available at: https://www.arca.fiocruz.br/bitstream/icict/26221/2/Livro\%20 EPSJV\%20013036.pdf. Accessed on: February 20, 2020.

CARSON, R. Primavera Silenciosa. Ed. Guaia, p. 327, 2010.

COUTO, M. C. L.; LANGE, L. C. Análise dos Sistemas de Logística Reversa no Brasil. Belo Horizonte, 2017.

FACCHINI, L. A.; SOUZA, L. E. de. Apresentação. In: CARNEIRO, Fernando Ferreira (Org.) Dossiê ABRASCO: um alerta sobre os impactos dos agrotóxicos na saúde / Organização de Fernando Ferreira Carneiro, Lia Giraldo da Silva Augusto, Raquel Maria Rigotto, Karen Friedrich e André Campos Búrigo. - Rio de Janeiro: EPSJV; São Paulo: Expressão Popular, 2015. 624p. Available at: https://www.arca.fiocruz.br/bitstream/icict/26221/2/Livro\%20EPSJV\%20013036. pdf. Accessed on: January 10, 2020.

GREENPEACE. Chega de veneno: por uma agricultura mais saudável e sustentável. Available at https://www.greenpeace.org/brasil/participe/chega-deagrotoxicos/?gclid=CjwKCAiA P3jBRAqEiwAZyWWaDL_oR4pDO6k6hxnCtlsZh0-vzRpdSFF1Sfs-7zVl_WSmE0Ca9bGLhoCvTMQAvD_BwE. Accessed on: March 06, 2020.

Instituto Nacional de Colonização e Reforma Agrária (INCRA). Sistema Nacional de Cadastro Rural. Índices básicos de 2013. Available at: http://www.incra.gov.br/tabela-modulo-fiscal. Accessed on: January 24, 2020.

Instituto Brasileiro de Geografia e Estatística - IBGE. Levantamento Sistemático da produção agrícola (2018). Available at: https:/www.ibge.gov.br/estatisticas/economicas/agricultura-epecuaria/9201-levantamento-sistematico-da-producao-agricola.html? $=\& t=0$-que-e. Accessed on: January 30, 2020.

Instituto Brasileiro de Geografia e Estatística - IBGE. Descrição agropecuária. Available at: http://www.bndes.cnpm.embrapa.br/textos/evolu1.htm. Accessed on: March 10, 2020.

Instituto Brasileiro de Geografia e Estatística - IBGE ( 2018). Cadastro Nacional de endereços para fins estatísticos. Available at: https:/www.ibge.gov.br/estatisticas/economicas/agriculturae-pecuaria/21814-2017-censo-agropecuario.html? edicao $=23751 \& \mathrm{t}=$ resultados. Accessed on: January 08, 2020.

Instituto Brasileiro de Geografia e Estatística - IBGE. Cidades. Available at: http://cidades.ibge. 
gov.br/comparamun/compara.php?lang $=\& \operatorname{coduf}=22 \&$ idtema $=162 \& \operatorname{codv}=$ v08\&search $=$ piau i| urucui| sintese-das-informacoes-2014\#. Accessed on: March 25, 2020.

Instituto Nacional de Processamento de Embalagens Vazias - INPEV. Preservar o campo limpo. Available at <http://www.inpev.org.br/sistema-campo-limpo/artigos/preservar-o-campo-limpo >. Accessed on: January 25, 2020.

Instituto Nacional de Processamento de Embalagens Vazias -INPEV. Relatório de sustentabilidade 2016. Available at: http://inpev.org.br/Sistemas/Saiba-Mais/Relatorio/inpEV_RS2016.pdf. Accessed on: January 10, 2020.

LEITE, P. R. Logística Reversa, Sustentabilidade e Competitividade. Teoria. Prática. Estratégias. São Paulo: Saraiva, 2017.

LIMA, L. B.; et al.. Uso de agroquímicos na produção de hortaliças em Farias Brito - CE. Brazilian Journal of Applied Technology for Agricultural Science, v.8, n.3, p.87-92, 2015.

Ministério da Agricultura, Pecuária e Abastecimento - MAPA (2019). Informações técnicas. Available at: http://www.agricultura.gov.br/assuntos/insumos-agropecuarios/insumos-agricolas/ agrotoxicos/informacoes-tecnicas. Accessed on: March 02, 2021.

OLIVEIRA, A. L.; CAMARGO, S. G. C.. Logística reversa de embalagens de agroquímicos: identificação dos determinantes de sucesso. Interciencia, 2014, v.39, n.11, p.780-787.

PADILHA, N. S.. Agrotóxicos e a saúde do trabalhador: a responsabilidade por contaminação do meio ambiente do trabalho. Revista Jurídica Luso-Brasileira, Ano 4 (2018), n. 6. Available at: http://www.cidp.pt/revistas/rjlb/2018/6/2018_06_0977_1006.pdf. Accessed on: January 23, 2020.

SOUSA, H. O. F; et al.. Percepção dos produtores rurais quanto ao uso de agrotóxicos. Revista Brasileira de Agricultura Irrigada. v. 10, n. 5, p. 976 - 989, 2016. Available at: http:/www.inovagri.org.br/revista/index.php/rbai/article/view/484. Accessed on: February 10, 2020 
Miguel Antônio Rodrigues

$\checkmark$ miguel.rodrigues@ifpi.edu.br

ORCiD: https://orcid.org/0000-0002-4893-174X
Submitted on: 22/05/2020

Accepted on: 24/05/2021

2021;24e:00711

\section{João Batista Lopes}

$\varangle$ lopesjb@uol.com.br

ORCiD: https://orcid.org/0000-0002-0133-4366

Elaina Aparecida da Silva

$\checkmark$ elaine@ufpi.edu.br

ORCiD: https://orcid.org/0000-0002-9476-930

How to cite: RODRIGUES, MA.; LOPES, JB.; SILVA, EA. Gestão das embalagens de agrotóxicos do Cerrado Piauiense. Ambiente $\&$ Sociedade. São Paulo, v. 24, p. 1-18, 2021. 


\title{
Gestão das embalagens de agrotóxicos do Cerrado Piauiense
}

\author{
Miguel Antônio Rodrigues \\ João Batista Lopes \\ Elaine Aparecida da Silva
}

São Paulo. Vol. 24, 2021

Resumo: $\mathrm{O}$ estudo objetivou analisar o papel dos atores da cadeia de Artigo Original logística reversa de embalagens de agrotóxicos utilizadas no Cerrado piauiense. Para tanto, foram realizadas entrevistas com representantes dos agentes da cadeia em quatro municípios que mais produzem soja no Piauí. Participaram da pesquisa representantes da Central, da Agência de Defesa Agropecuária do Piauí, da agricultura empresarial e da agricultura familiar. Constatou-se que, apesar de iniciativas positivas como a atuação de centrais de recebimento de embalagens, de produtores e do poder público, há muito a ser feito para que haja minimização dos impactos negativos à natureza e os consequentes danos à saúde das pessoas, visto que existem falhas nos mecanismos de fiscalização do poder público juntos às unidades de produção agrícola que fazem uso diariamente dos agrotóxicos. Assim, é necessário ação conjunta dos agentes da cadeia de logística reversa, iniciada no poder público e disseminada nos demais eles da cadeia.

Palavras-chave: Agricultura empresarial e familiar, logística reversa, fiscalização.

Como citar: RODRIGUES, MA.; LOPES, JB.; SILVA, EA. Management of agricultural pesticide packaging in the Piauí Cerrado. Ambiente $\mathbb{\&}$ Sociedade. São Paulo, v. 24, p. 1-18, 2021. 


\title{
Manejo de plagas de paquetes agrícolas en el Piauiense del Cerrado
}

\author{
Miguel Antônio Rodrigues \\ João Batista Lopes \\ Elaine Aparecida da Silva
}

São Paulo. Vol. 24, 2021

Resumen: El estudio tuvo como objetivo analizar el papel de los actores

Artículo original

en la cadena logística inversa de los envases de pesticidas utilizados en el Cerrado de Piauí. Con este fin, se realizaron entrevistas con representantes de agentes de la cadena en cuatro municipios que más producen soja en Piauí. Se descubrió que, a pesar de iniciativas positivas como el desempeño de los centros de recepción de envases, los productores y el gobierno, hay mucho por hacer para minimizar los impactos negativos en la naturaleza y el consiguiente daño a la salud de las personas, ya que que existen fallas en los mecanismos de inspección por parte de las autoridades públicas junto con las unidades de producción agrícola que hacen uso diario de pesticidas. Por tanto, es necesaria la actuación conjunta de los agentes de la cadena de logística inversa, iniciada por los poderes públicos y difundida al resto de la cadena.

Palabras-clave: Agricultura empresarial y familiar, logística inversa, inspección.

Como citar: RODRIGUES, MA.; LOPES, JB.; SILVA, EA. Manejo de plagas de paquetes agrícolas en el piauiense del cerrado. Ambiente $\mathbb{E}$ Sociedade. São Paulo, v. 24, p. 1-18, 2021.

DOI: http://dx.doi.org/10.1590/1809-4422asoc20200071r1vu2021L4AO 